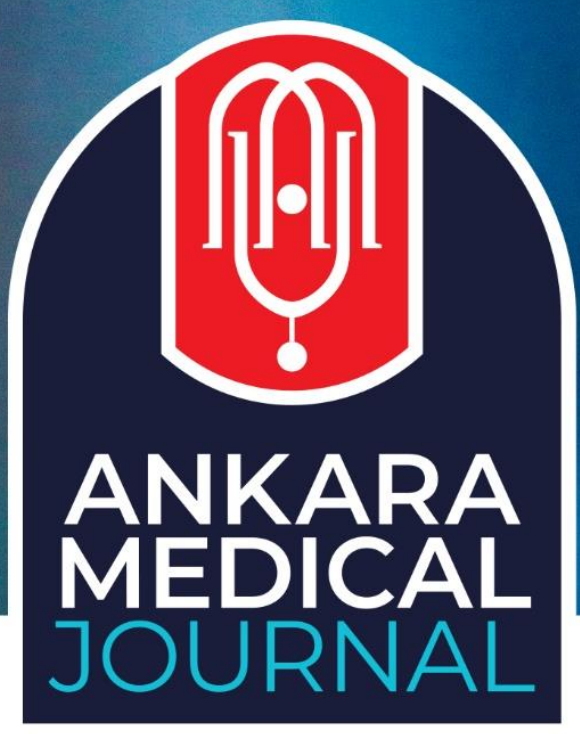

Research Article

Ankara Med J, 2021;(1):124-133 // đoi 10.5505/amj.2021.70037

\title{
RETROSPECTIVE EXAMINATION OF PATIENTS DIAGNOSED WITH AORTIC DISSECTION IN THE EMERGENCY DEPARTMENT AND UNDERGOING THIOL / DISULFIDE HOMEOSTASIS
}

\section{ACİL SERVİSTE AORT DİSEKSİYONU TANISI ALAN VE THİOL / DİSÜLFİ HOMEOSTAZİII ÇALIŞILAN HASTALARIN GERİYE DÖNÜK İNCELENMESİ}

(D) Nazlı Görmeli Kurt' ${ }^{1}$, (D) Servan Gökhan², (D) Ozcan Erel ${ }^{3}$

(D) Celal Güneş4, (D) Çağdaş Yıldırım², (D) Ayhan Özhasenekler²

(iD) Fatih Ahmet Kahraman²

1Department of Emergency Medicine, Ankara City Hospital, Ankara

2Department of Emergency Medicine, School of Medicine, Ankara Yıldırım Beyazıt University, Ankara

${ }^{3}$ Department of Biochemistry, School of Medicine, Ankara Yıldırım Beyazıt University, Ankara

${ }^{4}$ Batman State Hospital, Department of Emergency Medicine, Batman,

Yazıșma Adresi / Correspondence:

Uzm. Dr. Nazlı Görmeli Kurt (e-mail: nazligormeli@yahoo.com)

Geliş Tarihi (Submitted): 24.12.2020// Kabul Tarihi (Accepted): 08.03.2021

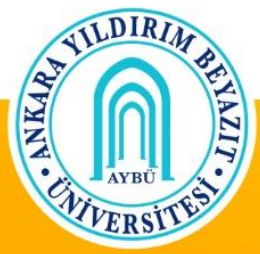

Ankara YIldırım Beyazıt University Faculty of Medicine

Department of Family Medicine 


\section{Öz}

Amaç: Akut aort diseksiyonu (AAD) olan hastalarda dinamik tiyol / disülfid homeostazındaki (TDH) değişiklikleri incelemek.

Materyal ve Metot: Çalışmamızda, Ocak 2015-Ocak 2018 tarihleri arasında Ankara Atatürk Eğitim ve Araştırma Hastanesi Acil servisine başvuran ve bilgisayarlı toraks tomografisinde AAD saptanan hastaların tıbbi kayıtları geriye dönük olarak gözden geçirildi. Çalışmada biri AAD, diğeri sağlıklı gönüllüler grubu olmak üzere iki grup mevcut idi. İlk olarak Erel ve Neșelioğlu tarafından tanımlanan spektrofotometrik yöntemle tiyol ve disülfid düzeyleri belirlendi, Doğal tiyol (NT), toplam tiyol (TT) ve disülfid (D) seviyeleri ve bunların birbirlerine oranları hesaplandı (indeks 1: D / NT, indeks 2: D / TT, indeks 3: NT / TT). Bu iki grubu Oksidatif stres parametreleri (Doğal Tiyol, Toplam Tiyol ve Disülfid seviyeleri) açısından karşılaştırdık.

Bulgular: Toplam 40 AAD hastası ve 38 cinsiyet ve yaş uyumlu sağlıklı gönüllü bu çalışmaya dahil edildi. Cinsiyet ve yaş açısından her iki grup arasında anlamlı fark yoktu (sırasıyla $p=0,923, p=0,401$ ). AAD grubu anlamlı olarak daha düşük doğal tiyol ve toplam tiyol'e sahipti $(p<0,001)$, ancak disülfid seviyeleri benzerdi $(\mathrm{p}=0,360)$. Oksitdatif stres parametreleri mortalite açısından istatistiksel olarak anlamlı bulunmadı. Sonuç: AAD'li hastalarda, özellikle native tiyol ve toplam tiyol olmak üzere, önemli ölçüde daha düşük tiyol / disülfid homeostazı saptadık. Oksidatif stres teorisinin AAD'nin patofizyolojisinde rol oynayabileceğini ve oksidatf stres paremetrlerinin tanı koymada yol gösterci olabileceği kanaatindeyiz.

Anahtar Kelimeler: Anevrizma, diseksiyon, oksidatif stres, sülfhidril bileşikleri, disülfidler.

\section{Abstract}

Objectives: To study changes in dynamic thiol/disulfide homeostasis (TDH) in patients with acute aortic dissection (AAD).

Materials and Methods: In our study, the medical records of patients who applied to Ankara Atatürk Training and Research Hospital between January 2015- January 2018 and were found to have AAD on computed tomography of the thorax were retrospectively reviewed. There were two groups in the study, one AAD group, and the other healthy volunteers' group. First, thiol and disulfide levels were determined with the spectrophotometric method defined by Erel and Neșelioğlu, natural thiol (NT), total thiol (TT), and disulfide (D) levels, and their ratios were calculated (index 1: D / NT, index 2: D / TT, index 3: NT / TT). We compared these two groups in terms of Oxidative stress parameters.

Results: A total of 40 patients with AAD and 38 age-matched healthy volunteers were included in this study. There was no significant difference between the two groups in terms of gender and age $(p=0.923, p=0.401$, respectively). The AAD group had significantly lower natural thiol and total thiol $(\mathrm{p}<0.001)$, but disulfide levels were similar $(\mathrm{p}=0.360)$. Oxidative stress parameters were not statistically significant in terms of mortality.

Conclusion: We found significantly lower thiol/disulfide homeostasis in patients with AAD, particularly native thiol and total thiol. We think that oxidative stress theory may play a role in the pathophysiology of AAD and oxidative stress parameters may guide the diagnosis.

Keywords: Aneurysm, dissection, oxidative stress, sulfhydryl compounds, disulfides. 


\section{Introduction}

Despite being a relatively rare acute cardiovascular event, acute aortic dissection typically has an acute presentation characterized by severe chest pain and acute hemodynamic compromise. Thus, to improve survival, it is imperative to diagnose it early and accurately during the presentation.

The International Registry of Acute Aortic Dissection (IRAD) established a current point of view about the disorder by creating a prospective database using worldwide data to help assess treatment success. IRAD has stated that the mortality from aortic dissection did not decline despite recent medical advances and remains as high as $25 \%$ to $30 \%$, due largely to systemic inflammatory response, higher oxidative stress, atherosclerosis, concealed disease, and delayed diagnosis. ${ }^{1,2}$

Early intervention and surgical repair are the mainstays of treatment to reduce mortality although medical treatment has traditionally failed to reach ideal outcomes. Effective medical treatment of AAD is yet lacking due to the absence of a clear understanding of the pathophysiology of the disease.

The hallmark histological features of AAD are excessive smooth muscle cell (SMC) loss, extracellular matrix degradation, and inflammation. Oxidative stress is activated by several stimulators to govern apoptosis and inflammation. Unopposed apoptosis brings about aortic inflammation and degeneration and results in AAD formation. ${ }^{3}$

Inflammation has been consistently documented to play an important role in the pathogenesis of aortic dissection. ${ }^{4}$ Reactive oxygen species (ROC) have also been shown by a huge body of literature to have a role in the occurrence of aortic dissection. ROSs are the spinoffs of mitochondrial energy metabolism, NADPH, xanthine oxidase, and uncoupled endothelial nitric oxide synthase. Antioxidants are responsible for the inactivation of ROS and include Superoxide Dismutase (SOD), catalase, glutathione peroxidase, albumin, uric acid, lactoferrin, $\beta$-carotene, and vitamins $C$ and E. ${ }^{5}$ Dynamic TDH mechanism has a pivotal role in the defense against oxidant molecules. ${ }^{6}$ The latter oxidized thiols to create disulfide bridges, which can also be reduced to thiol groups. ${ }^{7}$ There are accumulating data on murine and human subjects which suggest that oxidative stress partakes in the development of AAD and aneurysm formation. ${ }^{8}$ ROSs are capable of altering the leading pathological processes that have a role in conditions including aortic dissection, some examples of which are matrix metalloproteinase expression and smooth muscle apoptosis.

Abnormal TDH has been implicated in the emergence of a number of disorders which include diabetes mellitus, cardiovascular disease, neoplasms, hypertension, chronic kidney disease, and aortic aneurysm. ${ }^{9,10}$ Erel and 
Neșelioğlu described a fully automated, never-used-before technique for the assessment of thiol/disulfide homeostasis, which enables measuring thiol and disulfide levels individually. ${ }^{6}$

As far as we know, thiol/disulfide homeostasis has never served to assess oxidative stress in studies on AAD. We thus attempted to study the dynamic thiol/disulfide homeostasis in AAD.

\section{Materials and Methods}

This study was designed retrospectively and enrolled 40 patients with AAD and 38 age- and sex-matched healthy volunteers. The study has been made at Ankara Atatürk Training and Research Hospital emergency service. AAD patients were diagnosed at the emergency department between 01.01.2015 and 01.01.2018. AAD was diagnosed by a combination of clinical history, transthoracic echocardiography, and contrast-enhanced computed tomography. The exclusion criteria included having any infectious disease, chronic inflammatory conditions (collagen tissue diseases, ischemic heart diseases, malignancies, etc, immuno-compromised patients, pregnancy or lactating, neoplasm, pulmonary embolism, simultaneous acute coronary syndromes, moderate-to-severe liver or kidney disease, and using antioxidants. The healthy control group consisted of patients over the age of 18 years, who were not pregnant or lactating, free of any chronic condition or medication use, and willing to take part in the study.

Blood samples were collected from all patients at emergency department admission, prior to administering any medical or surgical urgent intervention. Parameters that are used to evaluate THD have been measured in an automatic analyzer by a novel spectrophotometric method which was developed by Erel and Neşelioğlu. ${ }^{6}$ This method was used to quantify the native thiol (NT), total thiol (TT), and disulfide (D) levels; subsequently, the three parameters were proportioned to one another to give index 1: D/NT, index 2:D/TT, and index 3 : NT/TT. ${ }^{6}$

\section{Statistical Analysis}

The study data were analyzed with BM SPSS Statistics for Windows, Version 22.0 (Armonk, NY: IBM Corp.) software package. Data distinction was tested with the Kolmogorov-Smirnov test. Normally distributed variables were reported as mean \pm standard deviation, and the non-normally distributed ones as median (minmax). The Mann-Whitney-U test was used to compare non-normally distributed variables and the independentsamples t-test was used to compare the normally distributed ones between two independent groups. A P value of $<0.05$ was considered statistically significant. 


\section{Results}

This study included a total of 40 patients, of which $34(85 \%)$ were male and $6(15 \%)$ were female. The patient group had a mean age of 57+17 years. In the healthy control group, thirty-two (84.20\%) cases were male, and $6(15.80 \%)$ were female; the control group had a mean age of $60+17$ years. The two groups were comparable with respect to sex and age ( $\mathrm{p}=0.923, \mathrm{p}=0.401$, respectively) (Table 1$)$.

The two groups significantly differed with respect to the NT and TT levels, with both levels being significantly lower in the patient group ( $\mathrm{p}<0.001$ and $<0.001$, respectively). They were, however, comparable in terms of the D ( $\mathrm{p}=0.360)$, index 1 ( $\mathrm{p}=0.358)$, index 2 ( $\mathrm{p}=0.358)$, and index 3 ( $\mathrm{p}=0.358)$ (Table 2). A ROC analysis was performed for both groups, the sensitivity, specificity, and the area under the curve of which for the NT and TT levels were shown in Figure 1.

A ROC analysis was performed for the control group and the patient group, with its sensitivity, specificity, for the NT and TT levels being shown in Figure 1. NT and TT values were found to be significant for use in discrimination of AAD. When we plotted the ROC curve, the area under the curve was found to be 0.751 (95\% CI 0.643-0.884; $\mathrm{p}=0.001$ ) and 0.723 (95\% CI 0.604-0.865; $\mathrm{p}<0.001$ ) for TT and NT values, respectively (Table 3 ). It is seen that the area under the curve is higher in the TT parameter. In Table 4, sensitivity and specificity values are given for some cut-off levels.

The deceased and surviving patients diagnosed with AAD at 30 days showed no significantly different NT, D, TT, and indexes 1, 2, 3 (Table 5).

Table 1. Demographic features of the groups

\begin{tabular}{|l|c|c|c|}
\hline & Control & Patient & p \\
\hline $\begin{array}{l}\text { Male Sex } \\
\mathrm{n}(\%)\end{array}$ & $32(84.20)$ & $34(85)$ & 0.923 \\
\hline $\begin{array}{l}\text { Mean Age } \\
\text { Mean } \pm \text { SD }\end{array}$ & $55.70 \pm 12.43$ & $56.41 \pm 9.87$ & 0.401 \\
\hline
\end{tabular}


Table 2. Thiol/disulfide homeostasis parameter levels among groups (control and patient groups)

\begin{tabular}{|c|c|c|c|c|c|c|c|c|c|c|c|c|c|}
\hline & \multicolumn{6}{|c|}{ CONTROL $(n=38)$} & \multicolumn{7}{|c|}{ PATIENT $(n=40)$} \\
\hline & Mean & SD & Median & Min & Max & $\begin{array}{c}\text { IQR/ } \\
\% 95 \text { CI }\end{array}$ & Mean & SD & Median & Min & Max & $\begin{array}{c}\text { IQR/ } \\
\% 95 \text { CI }\end{array}$ & $\mathbf{p}$ \\
\hline NT* & 427.81 & 74.75 & 435.00 & 186.00 & 578.30 & 403.24 & 311.45 & 73.06 & 292.15 & 135.0 & 459.10 & 288.08 & $<0.001$ \\
\hline $\mathrm{D}^{*}$ & 18.25 & 6.85 & 17.93 & 3.85 & 33.00 & 16.00 & 16.42 & 10.31 & 14.40 & 2.25 & 58.75 & 13.11 & 0.360 \\
\hline $\mathrm{TT}^{* *}$ & 464.4 & 75.6 & 470.9 & 215.0 & 607.3 & 85.7 & 344.3 & 77.1 & 317.5 & 162.2 & 513.2 & 121.5 & $<0.001$ \\
\hline index $1^{* *}$ & .044 & .017 & .048 & .008 & .075 & .024 & .055 & .034 & .045 & .008 & .166 & .046 & 0.358 \\
\hline index $2 * *$ & .040 & .015 & .044 & .008 & .065 & .020 & .048 & .027 & .041 & .008 & .125 & .037 & 0.358 \\
\hline index $3^{* *}$ & .920 & .030 & .912 & .865 & .984 & .041 & .903 & .053 & .917 & .751 & .985 & .075 & 0.358 \\
\hline
\end{tabular}

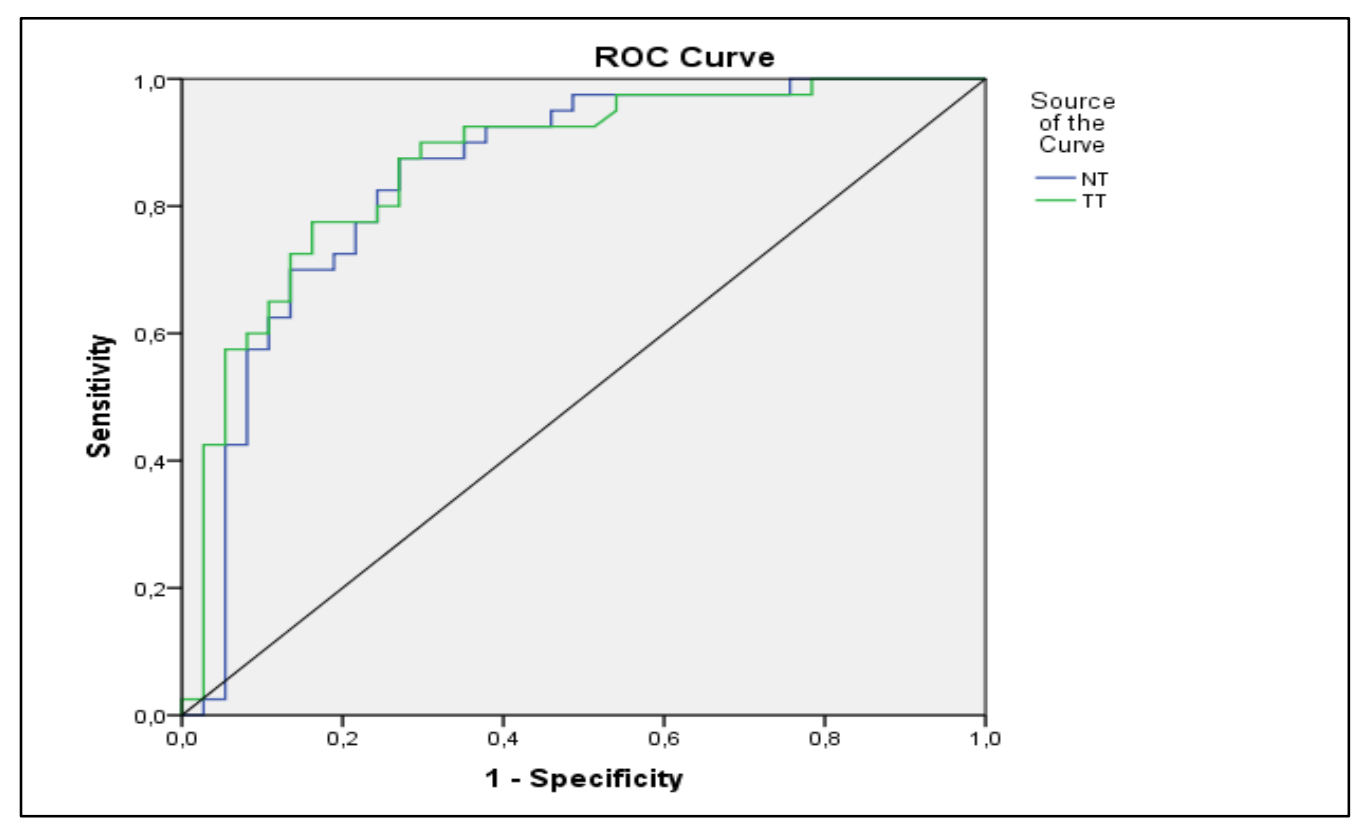

Figure 1. ROC analysis of TDH parameters 
Table 3. Area Under the Curve

\begin{tabular}{|l|c|c|c|c|c|}
\hline & & & & \multicolumn{2}{|c|}{$\begin{array}{c}\text { Asymptotic 95\% Confidence } \\
\text { Interval }\end{array}$} \\
\cline { 4 - 6 } Test Result Variable(s) & Area & Std. Error & Asymptotic \\
Sig. & 0,001 & Lower Bound & Upper Bound \\
\cline { 5 - 6 } & & 0,751 & 0,065 & 0,643 & 0,884 \\
\hline NT & 0,723 & 0,063 & 0,000 & 0,604 & 0,865 \\
\hline
\end{tabular}

The test result variable(s): NT, TT has at least one tie between the positive actual state group and the negative actual state group. Statistics may be biased.

a. Under the nonparametric assumption

b. Null hypothesis: true area $=0.5$

Table 4. Specificity and sensitivity rates for the TT parameter

\begin{tabular}{|l|c|c|c|}
\hline \multirow{2}{*}{ Test Result Variable(s) } & $\begin{array}{c}\text { Positive if less than or } \\
\text { equal to }\end{array}$ & Sensitivity & Specificity \\
\hline \multirow{4}{*}{} & 447,13 & 0,850 & 0,580 \\
\cline { 2 - 4 } & 382,08 & 0,760 & 0,670 \\
\cline { 2 - 4 } & 392,26 & 0,470 & 0,870 \\
\cline { 2 - 4 } & 439,34 & 0,890 & 0,410 \\
\hline
\end{tabular}

The test result variable(s): NT, TT has at least one tie between the positive actual state group and the negative actual state group.

a. The smallest cutoff value is the minimum observed test value minus 1 , and the largest cutoff value is the maximum observed test value plus 1 . All the other cutoff values are the averages of two consecutive ordered observed test values. 
Table 5. Thiol/disulfide homeostasis parameters and patients 30 day-mortality

\begin{tabular}{|c|c|c|c|c|c|c|}
\hline & $\begin{array}{c}\text { 30-day } \\
\text { mortality }\end{array}$ & $\mathbf{n}$ & Mean & $\mathbf{S D}^{*}$ & $\% 95 \mathrm{CI}^{* *}$ & $\mathbf{P}$ \\
\hline \multirow{2}{*}{$\mathrm{NT} \dagger$} & No & 35 & 313.32 & 74.55 & 287.71 & \multirow{2}{*}{0.674} \\
\hline & Yes & 5 & 298.36 & 67.46 & 214.58 & \\
\hline \multirow{2}{*}{$\mathrm{D}^{\dagger \dagger}$} & No & 35 & 16.76 & 10.84 & 13.03 & \multirow{2}{*}{0.581} \\
\hline & Yes & 5 & 13.99 & 5.43 & 7.24 & \\
\hline \multirow{2}{*}{ TT§ } & No & 35 & 346.84 & 79.49 & 319.53 & \multirow{2}{*}{0.585} \\
\hline & Yes & 5 & 326.34 & 61.56 & 249.89 & \\
\hline \multirow{2}{*}{ Index 1} & No & 35 & 0.056 & 0.035 & 0.04 & \multirow{2}{*}{0.719} \\
\hline & Yes & 5 & 0.050 & 0.024 & 0.02 & \\
\hline \multirow{2}{*}{ Index 2} & No & 35 & 0.048 & 0.027 & 0.04 & \multirow{2}{*}{0.762} \\
\hline & Yes & 5 & 0.044 & 0.020 & 0.02 & \\
\hline \multirow{2}{*}{ Index 3} & No & 35 & 0.902 & 0.055 & 0.88 & \multirow{2}{*}{0.762} \\
\hline & Yes & 5 & 0.910 & 0.040 & 0.86 & \\
\hline
\end{tabular}

${ }^{*}$ SD: standard deviation; ${ }^{* *} \mathrm{CI}$ : confidence interval, Index 1: D/NT; Index 2: D/TT; Index 3: NT/TT; ${ }^{\dagger} \mathrm{NT}$ : native thiol; ${ }^{\dagger+\mathrm{D}:}$ disulfide; § TT: total thiol.

Independent-samples t-test (mean; SD; 95\% CI).

\section{Discussion}

Our study demonstrated that the patient group, as compared to the controls, had significantly lower NT and TT, but not D, index 1, index 2 , and index 3 . As far as we know, our study, for the first time in the literature, showed that the TDH is altered in favor of disulfide bond formation, i.e. oxidative stress, which was demonstrated by a simple and safe method. This suggests the importance of thiols having a central role in mitigating oxidative stress by virtue of their -SH group. ${ }^{11}$-SH groups of proteins are primarily targeted by ROS. ROS oxidize -SH groups and make them form disulfide bonds that may be reduced by anti-oxidants to thiol groups again, which keeps the thiol-disulfide homeostasis intact. The basic molecular mechanism underlying proteins' structural and functional alteration is the loss of their thiol groups. ${ }^{12}$ Several observational studies have pointed to locally increased ROS levels as the major mechanism underlying the pathogenesis of AAD. ROS may induce vascular smooth muscle proliferation or apoptosis, and their relative degree deduces the role of oxidative stress. ${ }^{13}$ Pathological states are characterized by inflammatory reaction-induced apoptosis directly stimulated or propagated by high ROS levels. ${ }^{14}$ The likelihood of dissection is reportedly increased by oxidative stress stimulating vascular smooth muscle cell apoptosis. ${ }^{15}$ Our results unequivocally point to strong activation of matrix metalloproteinases, the enzymes which are implicated in the pathogenesis of AAD; furthermore, ROSs also effectively disintegrate extracellular matrix. ${ }^{3}$ A deficient thiol/disulfide homeostasis has been consistently shown by former studies on a number of disorders such as cardiovascular disease, atherosclerosis, hypertension, pulmonary embolism, acute myocardial infarction as well as type I diabetes mellitus; we also 
consider increased ROS levels causing heightened oxidative stress led to meaningful reductions in NT and TT levels in patients with AAD. ${ }^{12,16,18}$

Several experimental trials have assigned a prognostic role to oxidative stress in acute aortic dissection; likewise; NT and D levels have come to the fore as strong predictors of death in a number of conditions. 3,19,20 We similarly showed lower TT, NT, and D levels in deceased patients, although this difference did not reach statistical significance. While the thiol-disulfide shift was observed under oxidative stress, it fell short to create statistical significance. In our opinion, a larger sample size could yield statistical significance.

\section{Conclusion}

Aortic dissection has a high mortality rate, which should definitely be early and accurately diagnosed. Clinicians should maintain a high degree of suspicion of this condition should patients present with suggestive symptoms. In the present study, we employed TDH parameters to assess oxidative stress in AAD. We are of the opinion that oxidative stress theory may play a role in the pathophysiology of AAD and oxidative stress parameters may guide the diagnosis.

\section{Limitations}

The clinical severity, anatomical features (size, place in classification, etc.), surgical treatment, and intensive care applications will affect the analysis results. Therefore, prospective studies in which the number of patients is increased are needed.

\section{Ethical considerations}

Ethical approval was received previously from Ylldırım Beyazıt University Medical Faculty Ethics Committee (no: 26379996/17).

\section{Conflict of Interest}

The authors have no conflicts of interest to declare.

\section{Financial Disclosure}

The authors declared that this study has received no financial support 


\section{References}

1. Hagan PG, Nienaber CA, Isselbacher EM et al. The International Registry of Acute Aortic Dissection (IRAD): new insights into an old disease. JAMA. 2000;283(7):897-903.

2. Li, DZ., Yu, J., Du, RS. et al. Thrombo-inflammatory status and prognosis of acute type A aortic dissection. Herz 2016;41:250-1 (doi:https://doi.org/10.1007/s00059-015-4356-6).

3. Liu W, Wang B, Wang T, et al. Ursodeoxycholic Acid Attenuates Acute Aortic Dissection Formation in Angiotensin II-Infused Apolipoprotein E-Deficient Mice Associated with Reduced ROS and Increased Nrf2 Levels. Cell Physiol Biochem. 2016;38(4):1391-405 (doi: 10.1159/000443082).

4. Huang CK, Luo J, Lai KP, et al. Androgen receptor promotes abdominal aortic aneurysm development via modulating inflammatory interleukin- 1alpha and transforming growth factor-beta1 expression. Hypertension 2015;66:881-91.

5. Katsoulis K, Kontakiotis T, Papakosta D, et al. Comparison of serum total antioxidant status between patients with community acquired pneumonia and severe asthma exacerbation. Hosp Chronic 2010;5(1):1-6.

6. Erel Ö and Neşelioğlu S. A novel and automated assay for thiol/disulfide homeostasis. Clin Biochem 2014;47(18):326-32.

7. Şener A, Çelik G, Özhasenekler A, et al. Evaluation of dynamic thiol/disulfide homeostasis in adult patients with community-acquired pneumonia, Hong Kong Journal of Emergency Medicine 2019;26(6):343-50.

8. Griendling KK, FitzGerald GA. Oxidative stress and cardiovascular injury: Part II: animal and human studies. Circulation 2003;108:2034-40.

9. Matteucci E, Giampietro O. Thiol signalling network with an eye to diabetes. Molecules. 2010;15:8890903.

10. Rodrigues SD, Batista GB, Ingberman M, et al. Plasma cysteine/cystine reduction potential correlates with plasma creatinine levels in chronic kidney disease. Blood Purif. 2012;34:231-7.

11. Banks PA, Bollen TL, Dervenis C, et al. Classification of acute pancreatitis - 2012: revision of the Atlanta classification and definitions by international consensus. Gut 2013;62:102-11.

12. Ergin M, Cendek BD, Avsar AF, et al. Dynamic thiol-disulfide homeostasis in Hyperemesis gravidarum. J Perinatol. 2015;35:788- 92.

13. Li WG, Stoll LL, Rice JB, et al. Activation of NAD(P)H oxidase by lipid hydroperoxides: mechanism of oxidant-mediated smooth muscle cytotoxicity. Free Radic Biol Med 2003;34:937-46.

14. Dimmeler S, Zeiher AM. Reactive oxygen species and vascular cell apoptosis in response to angiotensin II and pro-atherosclerotic factors. Regul Pept 2000;90:19-25. 
15. Das D, Gawdzik J, Dellefave-Castillo L, et al. S100A12 expression in thoracic aortic aneurysm is associated with increased risk of dissection and perioperative complications. J Am Coll Cardiol 2012;60:775-85.

16. Kundi H, Ates I, Kiziltunc E, et al. A novel oxidative stress marker in acute myocardial infarction; thiol/disulfide homeostasis. Am J Emerg Med 2015;33:1567-71.

17. Ashfaq S, Abramson JL, Jones DP et al. The relationship between plasma levels of oxidized and reduced thiols and early atherosclerosis in healthy adults. J. Am. Coll. Cardiol. 2005;47(5): 1005-11 (doi:10.1016/j.jacc.2005.09.063).

18. Ates, I, Ozkayar N, Altay $\mathrm{M}$ et al. Is disulfide/thiol ratio related to blood pressure in masked hypertension? Clin. Exp. Hypertens. 2016;38(2):150-4.

19. Topuz M, Kaplan M, Akkus 0 et al. The prognostic importance of thiol/disulfide homeostasis in patients with acute pulmonary thromboembolism, American Journal of Emergency Medicine, 2016;34(12): 2315-9 (doi:10.1016/j.ajem.2016.08.039).

20. Tanriverdi F, Yuzbasıoglu Y, Haydar F, et al. Evaluation of Thiol Disulphide Homeostasis and Neutrophile Lymphocyte Ratio in Carbon Monoxide Intoxication. Ankara Med J. 2020;20(1):47-56 (doi:10.5505/amj.2020.71542). 